\title{
Introduction of ginger (zingiber officinale) plant in surkhandaryo soil-climate conditions
}

\author{
Kadirova Dilbar Normuminovna ${ }^{1}$, Abdullayeva Gulnoza Komiljonovna ${ }^{2}$ \\ ${ }^{1}$ Termez State University Candidate of Biological Sciences Associate professor. \\ ${ }^{2}$ is a master $\square$ s student of two course in the specialty of Master $\square$ s Degree in biology (science) of Termez State \\ University.
}

\begin{abstract}
To observe the growth and development of Ginger (Zingiber officinale) in the soil-climatic conditions of Termez district of Surkhandarya region and to conduct research and experiments on the plant to study the effects of environmental factors on the plant. Selection of experimental options and observations. Under the influence of external environmental factors, the plant sprouts at different times. The medicinal properties of the plant are also being studied in the literature.
\end{abstract}

Keywords: Ginger, growth, development, phenological, physiological indicators.

\section{INTRODUCTION}

The Resolution of the President of the Republic of Uzbekistan dated April 10, 2020 "On measures for the protection, cultivation, processing and rational use of available resources of wild-growing medicinal plants" was adopted. According to the resolution, in recent years, the Republic has been carrying out consistent reforms in the field of protection of medicinal plants, rational use of natural resources, the establishment and processing of plantations for the cultivation of medicinal plants.

Of the more than 4,300 plants belonging to the local flora, 750 species are medicinal, of which 112 species are registered for use in scientific medicine, of which 70 species are actively used in the pharmaceutical industry. In 2019, \$ 48 million worth of processed medicinal plant products were exported.

At the same time, the analysis shows the need of creation a value chain through the protection of medicinal plants, the organization of their plantations, processing.

Therefore, in Surkhandarya region, scientific research is being conducted on the climate and reproduction of medicinal plants.

region is located in the southernmost part of the country, the territory of the region is crossed by lines 370 101-390 021 northern latitude and 660 321-680 251 eastern longitude.

Surkhandarya region is located in the southernmost part of the country, the territory of the region is crossed by lines 370 101-390 021 northern latitude and 660 321-680 251 eastern longitude.

The peripheral (at the same time southern geographical) location of the Churkhandarya region requires that it be bordered by more foreign countries than other regions. It is bordered by foreign countries to the north, northeast and east, Tajikistan to the west, Turkmenistan to the west, and Afghanistan to the south by the Amu Darya River. The region is also bordered on the west by the high mountains to the Kashkadarya region of the country. The boundary line of this border corresponds to the edges of the Gissar ridge, the highest mountain of the republic. Kushtang (the highest peak in the region is $3723 \mathrm{~m}$ above sea level), Ketmonchopti (3168), Sarimas (1890 m) Waterless Mountain $(2122 \mathrm{~m})$, This border, which passes through Kulbatog $(2130 \mathrm{~m})$, is well separated. The area is reminiscent of a drawn triangle. Its dimensions are 220-250 km from north to south and 150-170 km from west to east. So it stretches from north to south. The province is surrounded on three sides by mountains, its border is open to the south, and its border with Afghanistan, which runs through the Amudarya River in the south, is very curved than the riverbed. The high mountains located on the western and north-western borders of Surkhandarya are the factors that create special climatic conditions in the region.

GINGER (Zingiber officinale. L) - a perennial herb with thick roots and stems, belonging to the class Ginger, family Ginger. Historically, ginger was used in the fourth century BC in the treatment of stomach aches, nausea, diarrhea.

Ginger has also been used as an appetite-boosting, immune-boosting drug. Ginger simultaneously improves gastric motility. Due to its safety, ginger is routinely used in pregnancy without adverse effects on the fetus.

Mainly distributed in the tropics and subtropics. It is grown in South and Southeast Asia. Ginger underground dried root is fragrant and delicious, with essential oil in all parts. The fragrant scent of unground ginger lasts longer 
than crushed. Talcum powder is used in medicine for the treatment of diseases of the liver, heart and stomach (it is drunk in a teapot with honey). In the food industry, it is used in the manufacture of confectionery and in cooking as a spice in some foods (before cooking).

Today, ginger is included in many natural medicines and is widely used in protecting the body from various ailments and in the fight against many diseases. The healing properties of ginger have been actively studied by modern experts for the last few decades. In particular, Ginger cleanses the liver and removes toxins from it, heals the gallbladder, is used to improve digestion.

Ginger;

- cleanses the liver and removes toxins from it;

- heals the gallbladder;

- warms the body from the inside;

- improves digestion;

- strengthens the immune system;

Undoubtedly, the popularity of ginger among many peoples of the world is due to its healing properties, which is due to its universal natural remedy in the prevention and treatment of diseases.

Seeds from the Republic of India were brought to the Surkhandarya Scientific Experimental Station of the Scientific Research Institute of Vegetable and Melon Crops and Potatoes in Termez district of Surkhandarya region on March 13, 2020 for the purpose of acclimatization (introduction) of ginger (Zingiber officinale L.). On March 14, the ground was prepared for sowing the seeds, and the ground was cleared of stones and similar foreign bodies. The seeds were divided using a knife before sowing, leaving one growth point on each seed.

Then, on the same day the seeds were sown in the ground at a depth of $10 \mathrm{~cm}$ and a depth of $4 \mathrm{~cm}$, with the growth buds facing upwards.

Seeds are sown and spread outside. Adaptation to climate. В. Alixonov, S. Самойлов, Р. Ibragimov UzbekRussian-English ecological dictionary.

Phenology (Greek "phainimena" - the phenomenon and the doctrine of "logy") is a system of knowledge about seasonal phenomena in nature, the dates of their onset, etc. The factors that determine these periods.

\begin{tabular}{|c|c|c|c|c|c|c|c|c|c|c|}
\hline \multicolumn{11}{|c|}{ ЗАНЖАБИЛ 03.08.2020 Й 1-варнант } \\
\hline $\begin{array}{l}\text { Ўсимлик кетма- } \\
\text { кетаити }\end{array}$ & 1- усаимих & 2- уанмлик & 3- уँсимлих & 4- усамлики & 5. ўсамлих & 6. ร̌симлих & $7 \cdot$ ỹcamsun & 8. ўсимиих & 9- у̃симлих & 10- у̃симлим \\
\hline $\begin{array}{l}\text { Асосий пояинит } \\
\text { узунлиги (си хисобияа) }\end{array}$ & 12 & 16 & 20 & 27 & 22 & 22 & 26 & 30 & 23 & 26 \\
\hline $\begin{array}{l}\text { Бир ўсимликдаги барг } \\
\text { сони (дона хисобида) }\end{array}$ & 9 & 10 & 10 & 11 & 10 & 8 & 10 & 9 & 8 & 7 \\
\hline $\begin{array}{l}\text { Sapr эни (2.6ўтимдан } \\
\text { олимган) (cм хисо6ияа) }\end{array}$ & 1 & 1.5 & 1.5 & 2 & 2 & 2 & 2 & 2 & 2 & 2.5 \\
\hline 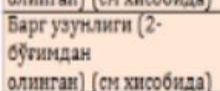 & 10 & 13 & 11 & 11 & 13 & 11 & 13 & 10 & 12 & 11 \\
\hline
\end{tabular}

\begin{tabular}{|c|c|c|c|c|c|c|c|c|c|c|}
\hline \multicolumn{11}{|c|}{ ЗАНЖАБИЛ 15.07.2020 Й 1-вариант } \\
\hline $\begin{array}{l}\text { Ўсимлик кетма- } \\
\text { кетлиги }\end{array}$ & 1. усимлик & 2- усимлик & 3- усимлик & 4 ўсимлик 5 & 5. усимлик & 6. усимлик & 7. усимлик & 8. усимлик & 9. уссимлик & 10- уссимлик \\
\hline $\begin{array}{l}\text { Асосий поянинг } \\
\text { узунлиги (см хисобида) }\end{array}$ & 11 & 20 & 16 & 23 & 23 & 16 & 23 & 23 & 21 & 16 \\
\hline $\begin{array}{l}\text { Бир ўсимликдаги барг } \\
\text { сони (дона хисобида) }\end{array}$ & 7 & 8 & 6 & 8 & 7 & 4 & 5 & 5 & 8 & 3 \\
\hline $\begin{array}{l}\text { Барг эни (2.бўғимдан } \\
\text { олинган) (см хисобида) }\end{array}$ & 1,5 & 2,5 & 2 & 2 & 2,2 & 1,8 & 2 & 2 & 2 & 2 \\
\hline $\begin{array}{l}\text { Барг узунлиги (2-бўғимдан } \\
\text { олинган) (см хисобида) }\end{array}$ & 9 & 14 & 10 & 11 & 14 & 10 & 12,5 & 12,5 & 11 & 6 \\
\hline
\end{tabular}




\begin{tabular}{|c|c|c|c|c|c|c|c|}
\hline \multicolumn{8}{|c|}{ ЗАНЖАБИЛ ЎСИМЛИГИДА ТРАНСПИРАЦИЯ ЖАДАЛЛИГИ 6.10.2020 } \\
\hline \multirow{3}{*}{ № } & \multirow{3}{*}{ Вақт } & \multirow[b]{2}{*}{ Барг юзаси } & \multicolumn{5}{|c|}{ ВАРИАНТЛАР } \\
\hline & & & $\begin{array}{c}\text { Органик ўғит } \\
\text { В1 }\end{array}$ & $\begin{array}{c}\mathrm{N}_{75} \mathrm{P}_{50} \mathrm{~K}_{50} \\
\mathrm{~B} 2\end{array}$ & $\begin{array}{c}\mathrm{N}_{125} \mathrm{P}_{100} \mathrm{~K}_{100} \\
\mathrm{~B} 3\end{array}$ & $\begin{array}{c}\mathrm{N}_{100} \mathrm{P}_{75} \mathrm{~K}_{75}+ \\
\mathrm{B} 3 \\
+\mathrm{Zn} 6+\mathrm{Fe} 6 \mathrm{~B} 4 \\
\end{array}$ & $\begin{array}{l}\text { Назорат } \\
\text { В5 } \\
\text { (ўғитсиз) }\end{array}$ \\
\hline & & $\begin{array}{c}10 \text { та у ўсимлик } \\
\text { хисобида }\end{array}$ & \multicolumn{5}{|c|}{ 10та ўсимлик барги оғирлиги ме хисобида } \\
\hline 1 & $8: 30$ & $2 \mathrm{~cm}^{2}$ & 735 & 765 & 635 & 710 & 620 \\
\hline 2 & 9:00 & $2 \mathrm{~cm}^{2}$ & 662 & 700 & 579 & 674 & 600 \\
\hline 3 & 9:30 & $2 \mathrm{~cm}^{2}$ & 615 & 665 & 542 & 629 & 588 \\
\hline 4 & $10: 00$ & $2 \mathrm{~cm}^{2}$ & 590 & 645 & 528 & 610 & 550 \\
\hline 5 & $12: 00$ & $2 \mathrm{~cm}^{2}$ & 537 & 590 & 480 & 565 & 440 \\
\hline 6 & $14: 00$ & $2 \mathrm{~cm}^{2}$ & 422 & 525 & 458 & 531 & 420 \\
\hline 7 & $16: 00$ & $2 \mathrm{~cm}^{2}$ & 380 & 454 & 435 & 497 & 370 \\
\hline
\end{tabular}

The letter "F" of the National Encyclopedia of Uzbekistan. State Scientific Publishing House "National Encyclopedia of Uzbekistan" Tashkent.

Ginger (Zingiber officinale.L) is monitored twice a month. In this process, the physiological and morphological characteristics of the plant are taken into account. Each month, the results are compared and differences are recorded. 
Table 3 above shows the transpiration rate in the plant.

In carrying out this experimental work, a sample of plant leaves of each variant is taken and the amount of evaporated water on the leaf surface of $2 \mathrm{~mm} 2$ is determined using a special scale. The process takes 15 minutes, Repeat between 30 minutes, 1 hour, and 2 hours to record the amount of water evaporated from the plant leaves. Experiments show that in plants of variant 2, the transpiration process is accelerated,

\section{List of used literature:}

1. Norbobaeva T. Classification of vegetation cover in South Uzbekistan / Узбекский биологический журнал -2004 -№1. $-\mathrm{S}$

2. Xo'jaev J. Plant physiology. T «Mehnat» 2004. 223 p.

3. S.S. Sahobiddinov, "Plant Systematics" Tashkent: Teacher 1996.

4. Transpiration (from the Latin trans, between and spiro - inhale, exhale) - the evaporation of water by plants. One of the important physiological processes is that it helps the plant to retain moisture continuously, ensures the influx of mineral salts from the soil, regulates tissue temperature, turgor level and protoplasm tension.

5. Hamdamov I and others. Basics of Botany Tashkent. Labor $1990 \mathrm{y}$.

6. N.X.Xolmatov, U. Kasimov "Dictionary of medicinal plants" Tashkent-1992

7. В. Alixonov, S. Самойлов, Р. Ibragimov Uzbek-Russian-English ecological dictionary.

8. National Encyclopedia of Uzbekistan. State Scientific Publishing House "National Encyclopedia of Uzbekistan" Tashkent.

9. Internet information

www.ziyouz.uz

www.darakchi.uz

https://ecolog.academic.ru

http://www.muslim.uz

https://uz.wikipedia.org/ 